\title{
Implementasi Konsep Budaya 5R (Ringkas, Rapi, Resik, Rawat Dan Rajin) Sebagai Upaya Meningkatkan Kinerja Perusahaan Dari Sisi Non Keuangan
}

\author{
Oleh : \\ Iman Sidik Nusannas. SS., ME \\ Program Studi Manajemen - STIE Dr. KHEZ Muttaqien
}

\begin{abstract}
$5 R$ or commonly known as $5 R$ (Seiri, Seiton,Seiso, Seiketsu, Shitsuke) a Japanese work culture first applied in Japan is now spread to the world. This $5 R$ motivate many enterprises to improve their work culture. This short study is to describe what is $5 R$, who should use this, and why it is powerful to increase a disciplin of an enterprise. Although has no direct relationship to increase profit, the kaizen way $5 R$ will guide an enterprise to an eficient management on many sector of company.
\end{abstract}

Key words: Kinerja Perusahaan, budaya perusahaan ,5R

\section{PENDAHULUAN}

Perubahan jaman semakin maju dan perkembangan teknologi yang semakin canggih menghasilkan berbagai inovasi dalam berbagai bidang kehidupan, termasuk bidang industri. Kemajuan inimemberikan banyak manfaat bila dapat dinikmati oleh banyak pihak (Kristanto Jahja, 2009).

Perubahan dunia industri semakin cepat, semakin banyak pula tuntutan kerja yang diinginkan perusahaan. Untuk mendukung pekerjaan agar dapat dilakukan lebih mudah dan lebih nyaman, salah satu yang harus dibangun adalah budaya kerja.

Budaya kerja di perusahaan perlu diciptakan dan dibutuhkan untuk perkembangan perusahaan dimasa yang akan datang dalam menghadapi tantangan di dunia industri. Perusahaan yang bergerak dalam proses manufacture memerlukan iklim kerja yang baik karena didalamnya terdapat sebuah proses produksi yang saling berkaitan antar lini. Proses produksi harus mengedapankan asas-asas efektifitas kerja, efisiensi, produktifitas dan keselamatan kerja agar produk yang dihasilkan memenuhi standar yang ditetapkan.

Unit paling dasar dalam produksi adalah machiningatau pemesinan. Unit machinery merupakan tempat proses produksi yang penting untuk mensuplai unitunit lain dalam proses produksi. Di dalam Unit Machinery and Tool terdapat proses pengerjaan mesin bubut, $\mathrm{CNC}$, frais, bor, gerinda, dan packaging yang membutuhkan ketelitian, keakuratan, ketepatan, dan kecepatan pendistribusian masing-masing komponen ke unitproduksi lain. 
Perusahaan melaksanakan MESH System (Management, Environment, Safety, and Health System) sebagai wujud kesadaran akan pentingnya keadaan lingkungan kerja, kesehatan dan keselamatan kerja. Salah satu cara mengimplementasikan MESH System dengan melakukan penerapan house keeping management dari Jepang, yaitu: 5R yang terdiri dari Seiri, Seiton, Seiso, Seiketsu dan Shitsuke.5R diartikan ke dalam bahasa Indonesia menjadi 5R yaitu: Ringkas, Rapi, Resik, Rawat dan Rajin. Sistem Housekeeping diterapkan karena terjadi ketidak teraturan penempatan tools di tempat kerja, khususnya departemen produksi. Program 5R diharapkan menghilangkan pemborosan yang ada dapat diminimalkan sehingga terjadi peningkatan produktifitas dan efektivitas dari perusahaan (Osada, 2011).

Metode 5R merupakan tahap untuk mengatur kondisi tempat kerja yang berdampak terhadap efektifitas kerja, efisiensi, produktifitas dan keselamatan kerja.Salah satu cara menciptakan suasana kerja yang nyaman adalah perusahaanmenerapkan sikap kerja 5R(Kristanto Jahja, 2009). Lingkungan kerja yang sebelumnya kurang nyaman bagi pekerja dapat diperbaiki dan disusun dengan program 5R.

Prinsip kerja 5R (Seiri, Seiton,Seiso, Seiketsu, Shitsuke) yang jika diterjemahkan akan menjadi 5R (Ringkas, Rapi, Resik, Rawat, Rajin). Hal tersebut berawal dari pelaksanaan 5R oleh Toyota Corporation, yang kemudian diikuti oleh berbagai perusahaan Jepang lainnya hingga menyebar ke berbagai perusahaan kelas dunia. Sama

\section{KAJIAN PUSTAKA}

\section{Budaya perusahaan}

\section{Konsep 5 R Sebagai Budaya Kerja}

Budaya perusahaan(corporate culture) sering diartikan sebagai nilai-nilai, simbol halnya dengan perusahaan di Indonesia, mereka juga menerapkan prinsip kerja ini sehingga menjadi budaya perusahaan.

Prinsip kerja 5R ini merupakan satu kesatuan dengan Kaizen (perubahan yang lebih baik) dimana pada prinsip kaizen terdapat dua hal penting yaitu kaizen 5R(perapihan lingkungan dan tempat kerja) dan kaizen proses. Jika kaizen 5R memulai dari hal-hal yang bersifat fisik seperti pengaturan persediaan, penempatan bahan baku, perapihan tempat kerja dan menempatkan segala sesuatu pada tempatnya, maka pada kaizen proses yang dilaksanakan adalah efisiensi sebuah proses pada sebuah alur kegiatan.

Prinsip kaizen 5R ini berhubungan dengan pengelolaan sumber daya manusia yang merupakan faktor penting bagi setiap organisasi, sebab tanpa sumber daya manusia, tujuan dan sasaran organisasi tidak akan tercapai sesuai yang direncanakan. Menurut Raymond A. Noe et. al (2010: 5) Human Resources Management (HRM) atau manajemen sumber daya manusia mengacu pada kebijakan-kebijakan, praktik-praktik serta sistem-sistem yang mempengaruhi perilaku, sikap dan kinerja karyawan.Dengan kata lain bahwa perilaku organisasi ialah apa yang dilakukan individu dalam organisasi yang dapat selalu diarahkan kearah yang positif, yaitu perilaku yang menunjang pencapaian sasaran organisasi secara efektif. Manajemen sumber daya manusia adalah suatu sistem yang saling berkaitan satu sama lain dengan mengatur dan memanfaatkan sumber daya manusia dari apa yang dimiliki oleh mereka untuk kepentingan perusahaan atau organisasi.

yang dimengerti dan dipatuhi bersama, yang dimiliki suatu organisasi sehingga anggota organisasi merasa satu keluarga dan menciptakan suatu kondisi yang berbeda dengan perusahaan lain. 
Pengertian budaya organisasi/perusahaan menurut Stephen Robbins dalam (Wibowo, 2010: 17) adalah sebuah persepsi umum yang dipegang oleh anggota organisasi dan merupakan suatu sistem tentang keberartian bersama, berkepentingan dengan bagaimana pekerja merasakan karakteristik suatu budaya organisasi.Karakteristik tersebut menangkap hakikat dari budaya suatu organisasi, sekaligus sebagai dimensi budaya organisasi. Karakteristik tersebut adalah sebagai berikut:

a. Inovasi dan keberanian mengambil risiko (Inovation and risk taking) adalah sejauh mana organisasi mendorong para karyawan bersikaf inovatif dan berani mengambil risiko selain itu bagaimana organisasi menghargai tindakan pengambilan risiko oleh karyawan dan membangkitkan ide karyawan.

b. Perhatian secara detail (Attention to detail), adalah sejauh mana organisasi mengharapkan karyawan memperlihatkan kecermatan analisis dan perhatian kepada rincian.

c. Berorientasi kepada hasil (outcome Orientation) adalah sejauh mana manajemen memusatkan perhatian pada hasil dibandingkan perhatian teknik dan proses yang digunakan untuk meraih hasil tersebut.

d. Berorientasi kepada manusia (People Orientation) adalah sejauh mana keputusan manajemen memperhitungkan efek hasil-hasil pada orang-orang di dalam organisasi

e. Berorientasi tim(Team Orientation) adalah sejauh mana kegiatan kerja diorganisasikan sekitar tim hanya pada individu-individu untuk mendukung kerjasama.

f. Agresifitas (Agressiveness) adalah sejauh mana orang-orang dalam organisasi itu agresif dan kompetitif untuk menjalankan budaya organisasi sebaik-baiknya.

g. Stabilitas (Stability) adalah sejauh mana kegiatan organisasi menekankan status quo sebagai kontras dari pertumbuhan penerapan dalam organisasi antara lain manajemen mempertahankan karyawan yang berpotensi evaluasi penghargaan dan kineja oleh manajemen ditekankan kepada upaya-upaya individual walaupun senioritas cenderung menjadi faktor utama dalam menentukan gaji atau promosi.

Menurut Umar (2010: 207) Budaya organisasi adalah suatu sistem nilai dan keyakinan bersama yang diambil dari pola kebiasaan dan falsafah dasar pendirinya yang kemudian berinteraksi menjadi normanorma, dimana norma tersebut dipakai sebagai pedoman cara berpikir dan bertindak dalam upaya mencapai tujuan bersama.

Geert Hofstede dalam (Wibowo, 2010: 15) menyatakan bahwa budaya terdiri dari mental program bersama yang mensyaratkan respon individual pada lingkungannya. Definisi tersebut mengandung makna bahwa kita melihat budaya dalam perilaku sehari-hari,tetapi dikontrol oleh mental program yang ditanamkan sangat dalam.

Sedangkan menurut Rivai dan Mulyadi (2012: 374), menyatakan bahwa Budaya organisasi adalah suatu kerangka kerja yang menjadi pedoman tingkah laku sehari-hari dan membuat keputusan untuk karyawan dan mengarahkan tindakan mereka untuk mencapai tujuan organisasi.

Berdasarkan pengertian di atas maka dapat di ambil kesimpulan bahwa budaya organisasi adalah sistem penyebaran kepercayaan dan nilai-nilai yang berkembang dalam suatu organisasi dan mengarahkan perilaku anggota-anggotanya, dengan kata lain bahwa budaya organisasi 
merupakan perilaku kolektif dari orang yang merupakan bagian dari sebuah organisasi, juga dibentuk oleh nilai-nilai organisasi, visi, norma, sistem dan simbol termasuk keyakinan dan kebiasaan.

\section{Proses Pembentukan Budaya Organisasi}

Proses pembentukan budaya organisasi menurut Kotler dan Heskett dalam (Tika 2010: 18) bisa berasal dari mana saja yaitu dari perorangan atas kelompok serta dari tingkat bawah atau puncak organisasi. Akan tetapi dalam perusahaan, gagasan ini sering dihubungkan dengan pendiri atau pemimpin awal yang mengartikulasikannya sebagai suatu visi, strategis bisnis, filosofi aatau ketiga-tiganya.Budaya Organisasi yang diciptakan oleh manajemen puncak kemudian diimplementasikan menjadi visi dan misi atau strategi bisnis.

Kemudian visi dan strategi itu diimplementasikan oleh anggota organisasi sehingga menjadi perilaku organisasi.Para manajer atau anggota senior kelompok organisasi mengkomunikasikan nilai-nilai pokok secara terus menerus dalam percakapan sehari-hari melaui ritual atau percakapan khusus sehingga mendorong anggota baru untuk menerapkan dalam beperilaku yang pada akhirnya dapat membawa organisasi memiliki budaya kuat yang berkinerja baik. Sesui dengan apa yang dikemukakan oleh (Robbins dan Coulter, 2012: 80-81) bahwa Suatu budaya yang kuat ditandai oleh nilai-nilai inti organisasi yang dipegang dan disepakati serta dijalankan oleh para anggotanya. Semakin banyak anggota organisasi menerima nilai-nilai inti dan semakin besar komitmen mereka terhadap nilai-nilai tersebut, semakin kuat suatu budaya.

\section{Faktor-faktor Pembentuk Budaya Organisasi}

Menurut Tika(2010: 5) ada beberapa unsur yang mempengaruhi terbentuknya budaya organisasi yaitu:

a. Asumsi dasar.

Asumsi dasar berfungsi sebagai pedoman bagi anggota maupun kelompok dalam organisasi untuk berperilaku.

b. Keyakinan untuk di anut.

Dalam budaya organisasi terdapat keyakinan yang di anut dan dilaksanakan oleh para anggota organisasi.Keyakinan ini mengandung nilai-nilai yang dapat terbentuk slogan atau motto, asumsi dasar, tujuan umum organisasi/perusahaan, filosofi usaha.

c. Pemimpin atau kelompok pencipta pengembangan budaya organisasi.

Budaya organisasi perlu diciptakan dan dikembangkan oleh pemimpin organisasi atau kelompok tertentu dalam organisasi tersebut.

d. Pedoman mengatasi masalah.

Dalam organisasi terdapat dua masalah pokok yang sering muncul, yakni masalah adaptasi eksternal dan integrasi internal.Kedua masalah tersebut dapat di atasi dengan asumsi dasar keyakinan yang di anut bersama anggota organisasi.

e. Berbagi nilai (Sharing Of Value).

Dalam budaya organisasi perlu berbagi nilai terhadap apa yang paling di inginkan atau apa yang lebih baik atau berharga bagi seseorang

f. Pewarisan (learning Process).

Asumsi dasar dan keyakinan yang di anut oleh anggota organisasi perlu diwariskan kepada anggota-anggota baru dalam organisasi sebagai pedoman untuk bertindak dan berperilaku dalam organisasi perusahaan tersebut.

g. Penyesuaian atau adaptasi. 
Perlu adanya penyesuaian terhadap pelaksanaan peraturan atau norma yang berlaku dalam organisasi tersebut, serta penyesuaian antara organisasi dengan perubahan lingkungan.

Kesimpulan dari penulis bahwa faktor-faktor pembentuk budaya organisasi, masing-masing unsur membantu menyatukan sebagai perekat organisasi yang membentuk suatu ciri khas perusahaan.

\section{Fungsi Budaya Organisasi}

Menurut Greenberg dan Baron dalam Wibowo (2011: 51) fungsi budaya organisasi adalah:

a. Memberikan rasa identitas

Semakin jelas persepsi dan nilai-nilai bersama organisasi didefinisikan, semakin kuat orang dapat disatukan dengan misi organisasi dan merasa menjadi bagian penting darinya.

b. Membangkitkan komitmen pada misi organisasi

Kadang-kadang sulit bagi orang untuk berpikir di luar kepentingannya sendiri, seberapa besar akan mempengaruhi dirinya. Tetapi apabila terdapat strong culture, orang akan merasa bahwa mereka menjadi bagian dari yang besar, dan terlibat dalam keseluruhan kerja organisasi.

c. Memperjelas dan memperkuat standar perilaku.
Budaya membimbing kata dan perbuatan pekerja, membuat jelas apa yang harus dilakukan dan kata-kata dalam situasi tertentu, terutama berguna bagi pendatang baru. Budaya mengusahakan stabilitas bagi perilaku, keduanya dengan harapan apa yang harus dilakukan pada waktu yang berbeda dan juga apa yang harus dilakukan individu yang berbeda disaat yang sama.

\section{Indikator Budaya Organisasi}

Budaya Organisasi menurut Hofstede (1993) dalam Fuad Mas'ud (2004) dapat dapat di bentuk oleh 5 indikator, Adapun indikator dari Budaya Organisasi dapat diartikan dalam empat konsep yaitu: Budaya Organisasi dapat diartikan dalam empat konsep yaitu:

a. Profesionalisme; mutu, kualitas dan tindak tanduk yang merupakan ciri suatu profesi dalam suatu Organisasi.

b. Jarak Manajemen; ketidakseimbangan dalam pembagian kekuasaan dalam organisasi dan anggota menganggap hal itu sebagai hal yang wajar.

c. Percaya pada rekan kerja ; Sikap yang timbul untuk mengakui dan meyakini kepada seseorang.

d. Integrasi; Suatu tindakan pembauran hingga menjadi kesatuan yang bulat dan utuh. 


\section{R Sabagai Budaya Kerja}

Salah satu konsepbudaya industri adalah budaya 5R.Konsep ini sederhana, mudah dipahami dan langkah awal penyebarluasan budaya industri. 5R berasal dari 5S, singkatan dari Seiri, Seiton, Seiso, Seiketsu dan Shitsuke. 5R berasal dari Jepang yang terkenal kemampuannya mengelola industry di Indonesia. Konsep 5R yang sederhana sering terabaikan. Industri tanpa 5R tak akan mampu berprestasi secara layak. Di Jepang orang menyebut 5R sebagai fondasi bagi semua jenis industri.5R memiliki pengertian tentang tempat kerja yang Ringkas, Rapi, Resik, Rawat dan Rajin.Penerapan konsep 5R merupakan landasan kokoh dalam menyongsong era industri. 5R merupakan budaya tentang bagaimana seseorang memperlakukan tempat kerja secara benar.Tempat kerja yang tertata rapi, bersih, dan tertib memudahkan pekerjaan perorangan. Dengan kemudahan bekerja ini, 4 bidang sasaran pokok industri berupa: efisiensi kerja, produktivitas kerja, kualitas kerja dan keselamatan kerja dapat mudah dipenuhi. Pemenuhan 4 bidang sasaran pokok ini merupakan syarat industri dalam berkembang di era globalisasi.Manfaat 5R bukan saja bagi perusahaan,juga bagi karyawan (Kristanto Jahja, 2009).

\section{Kaizen 5R}

Setelah perang dunia II berakhir, Jepang membangun kembali negara dan perekonomiannya. Untuk mencapai tujuan itu diperlukan strategi untuk maju. Prof. Edward Deming, seorang ahli statistik telah mempelajari proses dan management. Dari studi yang dilakukan disdapat kesimpulan bahwa di proses apa pun terutama bisnis banyak waste atau limbah. Agar didapat hasil yang lebih baik maka diperlukan kerja yang lebih dan memfokuskan padawaste elimination. Perbaikan tidak perlu makan waktu yang lama untuk menunggu inovas karena menunggu inovasi juga waste di waiting. Yang lebih penting adalah siklus pemikiran sampai implementasi dilakukan terus bertahap, terus menerus. Ide Deming tidak populer di Amerika yang sedang dominasi ekonomi dunia saat itu.

$5 \mathrm{R}$ adalah proses perubahan sikap dengan menerapkan pemilahan ditempat kerja, mengadakan penataan, pembersihan, memelihara kondisi yang mantap dan melakukan pemeliharaan terhadap kebiasaan - kebiasaan yang diperlukan untuk melaksanakan pekerjaan supaya hasilnya bisa menjadi lebih baik. 5R atau $5 \mathrm{~S}$ berasal dari kata dalam bahasa Jepang yaitu Seiri, Seiton, Seiso, Seiketsu dan Shitsuke atau dalam bahasa Indonesia berarti $5 \mathrm{R}$ yaitu Ringkas, Resik, Rapi, Rawat, Rajin. Penjelasan dari masing-masing $\mathrm{S}$ pada 5R menurut Osada (1995) yaitu :

a. Seiri, berarti mengatur segala sesuatu, memilah sesuai dengan aturan atau prinsip tertentu yang ditetapkan baik berdasarkan yang diperlakukan dengan yang tidak diperlukan dan klasifikasi.

b. Seiton, berarti menyimpan barang ditempat yang tepat atau seharusnya dengan tujuan untuk mengurangi waktu proses karena pencarian. Penataan diawali dengan studi efisiensi intensif dan mendetail. Berikut ini adalah beberapa hal yang diperhatikan dalam menerapkan Seiton :

1. Eliminasi barang yang tidak digunakan

2. Penyimpanan barang tak terduga

3. Penyimpanan barang yang jarang digunakan

4. Penyimpanan barang yang sewaktu-waktu digunakan 
5. Penyimpananbarang yang sering digunakan di area kerja atau penyimpanan pribadi oleh pekerja.

Penyimpanan barang atau alat berdasarkan pada intensitas pemakaian dankeperluan agar mudah ditemukan dalam pencarian. Efisiensi, kemanan, mutupenyimpanan dan area tata letak juga harus diperhatikan agar barang yangdisimpan tetap dapat mendukung kelancaran dalam bekerja dan menyingkatwaktu proses produksi.

c. Seiso, berarti pembersihan yaitu membersihkan barang-barang atau area kerjamenjadi bersih dan bebas dari kotoran dan sampah yang mengganggukelancaran proses produksi. Istilah $5 \mathrm{R}$ pembersihan berarti membuangsampah, kotoran, benda-benda asing, serta membersihkan segala sesuatu.Pembersihan merupakan satu bentuk dari pemeriksaan. Langkahlangkahdalam pembersihan yaitu:

1. Membersihkan segala sesuatu dan menangani keseluruhannya (makro).

2. Membersihkan tempat kerja dan bagian mesin khusus (individual).

3. Membersihkan bagian dan alat khusus, serta mengidentifikasi penyebab kotoran untuk dibersihkan (mikro).

d. Seiketsu, berarti pemantapan yaitu pemeliharaan secara terus menerus danberulang-ulang dari $3 \mathrm{~S}$ yang telah dilakukan yaitu pemilahan, penataan danpembersihannya.Pemantapan mencakup kebersihan pribadi danlingkungannya.Pemantapan memerlukan manajemen visual yang dapatdilakukan dengan pemberian kode warna, label dan peta. e. Shitsuke, berarti pembiasaan mengenai disiplin dan pembentukan perilakusecara benar dan yang baik di tempat kerja. Penerapan 5R tidak akan berhasiltanpa pembiasaan. Salah satu cara pembiasaan adalah dengan merancangdaftar periksa atau checksheet yang juga merupakan bentuk daripengontrolan terlaksananya $5 \mathrm{R}$.

Penerapan 5R memberikan banyak keuntungan baik secara langsung maupun tidak langsung. Menurut Osada (1995) keuntungan yang diperoleh darimenerapkan 5R antara lain:

a. Tempat kerja yang menyenangkan. Tempat kerja yang bersih, rapi dan teratur memungkinkan pekerja lebihtermotivasi dan bersemangat untuk bekerja.

b. Mengefisienkan pekerjaan. Waktu yang digunakan untuk mencari barang atau peralatan yang dibutuhkan mempengaruhi keefisienan pekerjaan. Penerapan 5R yangmemperhatikan peletakan dan penataan keperluan ditempat yang mudahdijangkau dan memudahkan proses pencarian membuat pekerjaan menjadilebih cepat dan efektif.

c. Memperkecil kecelakaan kerja. Lingkungan yang menerapkan konsep 5R akan membawa pekerja untukbekerja dilingkungan yang bebas bahaya maupun kecelakaan kerja.Lingkungan kerja yang rapi dah bersih dari penerapan 5R berarti menjaminkeselamatan kerja dan menghindarkan pekerja dari bahaya yang mungkintimbul dari lingkungan yang berantakan dan tidak sehat.

d. Kualitas produk yang lebih baik dan peningkatan produktivitas. Perusahaan yang telah menerapkan 5R menunjukkan jumlah cacat 
yangrelatif lebih rendah dari pada perusahaan yang belum menerapkan karenamenerapkan 5R berpengaruh kepada produktivitas kerja yang lebih baik.

Sasaran program 5R yang dirumuskan Quality Productivity Development ( 1989 )adalah sebagai berikut:

a. Terciptanya tempat kerja yang bersih, cerah, teratur dan menyenangkan.

b. Terawatnya peralatan dan perlengkapan, serta bangunan selama proseskerja.

\section{Strategi Menerapkan Metode Kaizen 5R/ 5S yang Effektif di Perusahaan}

Seperti yang diungkapkan seorang ahli kaizen (Wolio; 2015) dalam Jurnal Teknik Indsutri. Keberhasilan banyak perusahaan di dunia dalam menerapkan metode $5 \mathrm{R}$ telah menjadi pijakan awal yang mendasar sebagai bagian yang fundamental dalam mencanangkan penerapan startegi perbaikan terus menerus (continuous improvement) sehingga menempatkan metode 5R sebagai salah satu elemen yang penting dalam melakukan penerapan Lean Management yang saat ini sedang populer.

5R adalah suatu sistem untuk mengurangi pemborosan dan mengoptimalkan produktivitas melalui terciptanya tempat kerja yang teratur, rapih, sistimatis dengan menggunakan isyarat visual untuk mencapai hasil operasional yang efektif jika jalankan dengan konsisten.

Secara historis 5R awalnya merupakan embrio dari karakter management gaya Jepang yang dikenal sebagai bagian dari manajemen tempat kerja yang paling fundamental dan sangat efektif untuk mendisiplinkan karyawannya dalam mengelola tempat kerja dengan rapih, bersih, terorganisir, produktif dan berbudaya. Seiring dengan perkembangannya yang pesat c. Terwujudnya disiplin kerja yang dibutuhkan untuk mencapai standar kerja.

d. Terjaganya keselamatan dan kestabilan kerja dan mutu hasil kerja selamaoperasi berlangsung.

e. Tercapainya perbaikan efisiensi dan efektivitas di masing-masing fungsi.

f. Terbinanya suasana kerja yang nyaman dan menyenangkan, berdisiplin dansaling menghargai antar pekerja.

dan banyak diadopsi oleh perusahaan utama di didunia saat ini, di Indonesia sistem ini dapat diterjemahkan dan dikenal dengan istilah 5R (Ringkas, Rapi, Resik, Rawat, Rajin).

Walaupun awalnya banyak yang menganggap 5R hanya sebatas program bersihbersih,namun seiring dengan perkembangannya ternyata telah terbukti bahwa apabila sistem ini diterapkan secara sungguh-sungguh, sistemik dan tepat sasaran ternyata secara lansung memiliki peranan yang cukup signifikan dalam menopang terciptanya budaya kerja produktif untuk menunjang peningkatan kinerja perusahaan yang berdampak pada efektifitas kapasitas produksi, peningkatan kualitas produk, pengurangan biaya, pengiriman tepat waktu, menjamin terciptanya keselamatan kerja serta meningkatkan pelayanan di beberapa perusahaan jasa yang menerapkannya. Selebihnya penerpan $5 R$ juga ternyata dapat menciptakan pola kerja dengan disiplin tinggi, bermoral dan lingkungan kerja yang terkontrol dengan suasana yang bersih/sehat dan nyaman sehingga dapat menciptakan kesan yang postif terhadap siapa saja termasuk para pelanggannya. Namun demikian, berdasarkan penelusuran kami, dilain pihak tidak sedikit perusahaan yang mencoba menerapkan metoda $5 \mathrm{R}$ justru merasa gagal dan tidak memberikan kontribusi yang berarti terhadap kinerja perusahaan yang ingin dicapai. Kenapa..? 
salah satu penyebabnya adalah tidak adanya komitmen bersama dan dukungan penuh yang konsisten dari level top manajemen dalam menjalankan sistem 5R. Harus disadari bahwa penerapan metoda 5R merupakan suatu pendekatan berbasis tim/kelompok yang memerlukan dukungan manajemen puncak dan keterlibatan semua karyawan di area kerja agar selalu perduli dengan lingkungan kerjanya melalui tindakan memantau, mengidentifikasi kemudian mengevaluasi atas dasar keperdulian yang tinggi untuk selalu melakukan perbaikan. Merujuk dari perusahaan yang berhasil menerapkan system ini dapat disimpulkan bahwa untuk memperoleh kinerja pelaksanaan 5R yang optimal sebaiknya dilakukan di bawah bimbingan seorang yang berpengalaman baik melalui pelaksana internal yang telah terlatih yang berasal dalam lingkup perusahaan yang bersangkutan maupun menyewa konsultan ahli untuk memberikan inhouse training 5R sebagai usaha untuk memberikan pemahaman standar kepada seluruh karyawan yang terkait. Kenapa ? karena melalui pelaksanaan pelatihan secara menyeluruh dan terprogres diharapkan seluruh karyawan akan dibekali pengertian yang memadai agar memiliki pola pikir yang sama dalam pelaksanaan tahapan tahapan penerapan 5R yang benar dan efektif.

Mereka-mereka yang terlibat dalam penanganan 5R diharapkan mampu mengatasi setiap aspek yang berpotensi menjadi sumber yang menyebabkan pemborosan yang banyak ditemukan di lingkungan kerja yang tidak teroganisir dengan baik bahkan secara visual dapat memperlihatkan kesan sangat semrawut dan berdampak buruk terhadap aspek produktifitas, biaya, qualitas produk maupun sistem pelayanan. Pelaksanaan metoda 5R bukalah tindakan kegiatan yang dilakukan sekali saja ataupun sesaat yang hanya dilakukan tergantung kondisi dan kemauan manajemen tingkat atas yang biasanya baru bereaksi untuk mengusulkan suatu tindakan perbaikan ketika terjadi permasalahan yang muncul secara mendadak, akan tetapi harus merupakan suatu kegiatan yang dilakukan secara rutin dalam konteks budaya perusahaan/organisasi yang harus dibangun sebagai wujud tindakan perbaikan yang spontan dan berkesinambungan. Sebagai suatu langkah awal yang strategis sebaiknya pelaksanaan 5R harus berawal dari merubah paradigma karyawan untuk mengatasi kurangnya toleransi karyawan terhadap sikap dan pola pikir dalam mengatasi hal-hal yang tidak standar yang biasa terjadi dalam suatu lingkungan kerja. Dalam level perusahaan/organisasi yang besar dan menengah, tahapan strategi yang efektif dalam memulai pelaksanaan metoda $5 \mathrm{R}$ dalam konteks perusahaan secara kolektif diseluruh bagian adalah sebagai berikut :

\section{a. Membentuk Team 5R}

Tahapan pertama yang harus ditempuh dalam menerapkan metode $5 \mathrm{R}$ adalah membentuk tim inti pelaksana $5 \mathrm{R}$ yang berasal dari berbagai departmen/bagian kerja. Anggota tim 5R harus terorganisir dengan baik serta dibekali pemahaman yang memadai tentang penerapan $5 \mathrm{R}$ yang sistematis dan tepat sasaran. Mengapa ? Karena apabila penguasaan/pemahaman 5R dari anggota tim yang terbentuk belum memungkinkan maka langkah yang harus ditempuh adalah mengutus beberapa diantara mereka untuk mendapatkan pembekalan pemahaman yang cukup melalui pelatihan penerapan 5R diluar lingkungan perusahaan. Alternatif lain yang sering dilakukan pihak perusahaan dapat mendatangkan trainer dari luar perusahaan untuk melakukan workshop pelatihan 5R yang bertujuan untuk mengoptimalkan pemahaman 
penerapan 5R. Cara ini akan lebih efektif karena selain dapat dijadikan sebagai ajang pengenalan 5R kepada seluruh anggota tim maupun karyawan, juga dapat merupakan momentum terciptanya inisiatif untuk mendapatkan ide/gagasan baru yang lebih baik dalam mengoptimalakan hasil penerapan 5R yang akan di jalankan.

b. Merancang Sistem Pelaksanaan 5R

Sebelum memulai, team harus menyusun dan merencanakan sistem pelaksanaan 5R yang baik sesuai kondisi aktual di perusahaan. Lakukan observasi di lapangan dengan melihat dan mengevaluasi lansung situasi kerja yang sebenarnya agar benar-benar mengacuh pada aktualisasi sistem kerja yang sedang berjalan dilapangan. Lihatlah situasi areal lingkungan kerja yang ada, bagaimana orang bekerja, seberapa jauh pekerjaan yang dilakukan dan alat-alat serta fasilitas yang digunakan di masing-masing bagian, bagaimana penanganan material dan bahan baku yang di

\section{c. Pilot Project 5R}

Saat rancangan prosedur pelaksanaan 5R terselesaikan, maka langkah selanjutnya adalah memulai menerapkan metoda pelaksanaan 5R sesuai prosedur aturan yang telah ditetapkan. Untuk skala perusahaan organisasi yang besar dan menengah, mengingat ketersediaan waktu dari beberapa bagian berbeda-beda untuk menetapkan kapan waktu yang tepat memulai menerapakan 5R maka cara yang efektif sebaiknya mengawali penerapannya pada salah satu area/dept. tertentu sebagai pilot project ( proyek percontohan) yang pelaksanaannya dapat dilakukan dengan melibatkan beberapa pihak dari lintas karyawan. Cara ini sangat efektif sebagai tahapan terapkan, apakah terdapat beberapa factor yang berpotensi menyebabkan kecelakaan dll. Simpulkan apakah semua aktifitas yang dilakukan berdampak besar terhadap timbulnya banyak gerakan yang tidak efektif karena factor manusia, alat, metoda kerja, linkungan kerja dan penyimpanan material yang kurang baik sehingga menjadi sumber yang berpotensi mendatangkan pemborosan. Dari catatan pemantauan yang dilakukan oleh tim, dapat menjadi alternatif pertimbangan dalam memetahkan rencana sistem pelaksanaan 5R yang baik. Metoda penerapan 5R adalah merupakan konsep tim yang dilakukan secara terpadu dan menyeluruh dalam suatu areal kerja, hal ini membutuhkan partisipasi semua pihak untuk merancang, pengimplementasikan dan mempertahankan itu semua sesuai dengan karakter tempat kerja dimasing masing

bagian.

awal yang berfungsi sebagai proyek percontohan yang selanjutnya dapat ditindaklanjuti dan diikuti penerapannya pada areal lain yang berbeda. Pelaksanaan pilot proyek akan lebih efektif jika dilakukan oleh tim 5R yang terpilih dalam suatu aktivitas workshop. Tim 5R yang terlibat harus melakukan evaluasi pelaksanaan dengan memantau aspek kelemahan yang masih berpotensi terjadi untuk kemudian dilakukan evaluasi dalam keperluan perbaikan yang lebih lanjut.

\section{d. Kick Off Penerapan 5R}

Ketika sistem 5R ingin diterapkan dan diperkenalkan kepada seluruh jajaran di perusahaan, pada umumnya diawali dengan event resmi semacam kick off sekaligus sebagai wadah pemberitahuan 
dimulainya penerapan $5 \mathrm{R}$ secara resmi kepada seluruh karyawan yang sebaiknya disampaikan secara resmi oleh jajaran direksi/pimpinan. Hal ini sangat penting sebab disamping wadah pemberian dukungan penuh pihak manajemen yang diperlihatkan kepada seluruh karyawan juga merupakan wujud tindakan keperdulian lansung yang dapat diharapkan sangat efektif dalam memompa semangat karyawan untuk maju dengan harapan dapat melahirkan komitmen kebersamaan yang kokoh dalam menjalankannya setiap sistem yang dapat memajukan perusahaan. Mengapa hal diatas dianggap penting ? Karena dari beberapa pemantaun kami, banyak perusahaan yang menerapkan system 5R tidak bisa berjalan dengan baik secara berkesinambungan sesuai dengan yang diharapkan karena tidak adanya komitmen dan dukungun penuh dari jajaran direksi maupun pimpinan perusahaan/instansi yang menyelenggarakannya. Kurangnya atau tidak adanya sosialisi pemahaman penerapan dan tujuan 5R kepada seluruh jajaran karyawannya juga merupakan suatu hal yang paling subtansial menyebabkan penerpan 5R gagal terimplementasikan. Pentingnya sebuah aktifitas kick-off dalam memulai sesuatu aktivitas yang berbasis kemajuan perusahaan adalah momen yang paling tepat untuk dapat mengumpulkan seluruh jajaran karyawan yang terlibat. Sehingga saat inilah yang paling tepat untuk membahas, menjelaskan hal-hal yang berhubungan dengan proyek serta meminta dukungan, komitmen serta kerjasama dari seluruh karyawan.

\section{e. Training 5R Training $5 R$}

Penerapan pendekatan 5R memiliki tahapan strategis yang diperlukan bagi setiap yang menjalankannya. Dibutuhkan suatu pelatihan yang memadai bagi karyawan yang ingin menerapakan metode 5R yang baik karena penguasaan metoda serta pengetahuan dasar bagaimana menjalankan 5R melalui tahapan training yang terpadu adalah sangat penting mengingat hal ini sangat berhubungan dengan kualiatas impelementasi riil di lapangan. Namunpun demikian awal pelaksanaan $5 \mathrm{R}$ harus dimulai dengan perubahan "mind set" karyawannnya sehingga dapat memperkokoh komitmen setiap pihak yang menjalankan. Ingat, bahwa penerapan 5R tidak harus disikapi sebatas aktifitas bersih-bersih di lingkungan kerja tapi selebihnya jika penerapannya dapat di rancang secara sistimatis dan terintagrasi maka akan mampu menjadi alat yang dapat mendisiplinkan dan membangun mental karyawan dalam bekerja. Oleh sebab itu desain system dan prosedurnya merupakan aspek yang harus diutamakan dan semua hal tersebut harus di bimbing dan diarahkan oleh seorang instruktur atau trainer yang berpengalaman. Terwujudnya pelaksanaan 5R yang sistimatis akan bermuara pada sasaran yang merupakan tahapan paling penting dari penerapan 5R dalam mendukung kualitas dan efisiensi karena hasil akhirnya dapat menyentuh pembangunan budaya yang positif pada lingkungan kerja itu sendiri.

\section{f. Melaksanakan Audit 5R}

Langkah yang paling benar dan tepat dalam menjamin pelaksanaan program pelaksanaan $5 \mathrm{R}$ yang stabil dan 
konsisten sesuai prosedur harus ditempuh pelaksanaan audit 5R yang efektif dimana dalam pelaksanaannya audit 5R dapat diterapkan secara terjadwal sebagai tindakan pengendalian yang terkontrol dan ketahui oleh semua pihak terkait. Disamping Pelaksanaan audit 5R perlu dilakukan secara terjadwal namun demikian pelaksanaan audit dengan sistem acak yang bersifat mendadak oleh pihak top management untuk mengindari pihak yang biasanya hanya menerapkan aktifitas pengendalian 5R, yang biasanya masih terdapat pihak pihak yang hanya melakukannya sebagai persiapan yang hanya dilakukan sebelum audit 5R dilakasanakan. Tujuan pelaksanaan audit diatas sedikitnya dapat memberikan sinyal pemberitahuan yang bersifat peringatan agar selalu konsisten dalam menerapakan kaidah 5R kepada setiap karyawan agar selalu memantau secara konsisten tentang kemajuan pelaksanaan 5R yang diterapkan. Yang paling penting, meninjau hasil dan item tindakan (yang baik dan yang buruk) dengan kelompok yang bertanggung jawab untuk area yang diaudit. Dengan selalu mengharapkan untuk mendapatkan umpan balik dan ide-ide karyawan.

\section{g. Visualisasi hasil pencapaian $5 \mathbf{R}$}

Visualisasi Kinerja 5R Setiap penerapan 5R memilki tujuan baik dan berdampak positif dalam menopang pencapaian visi suatu perusahaan sesuai dengan yang diharapkan yaitu terciptanya lingkungan kerja yang bersih, rapih, terorganisir hingga dapat menciptakan disiplin karyawan yang tinggi dalam bekerja. Untuk menjamin pengelolaan yang baik dan konsisten dibutuhkan tranparansi melalui visualisasi pencapaian kinerja penerapan 5R agar diketahui semua pihak mulai dari level pelaksanan, jajaran manajemen, bahkan customer maupun siapa saja yang berada dilingkungan kerja. Penerapan sistem visual management menyangkut pencapaian 5R pada beberapa perusahaan menggunakan papan board yang mudah diakses oleh siapa saja dengan menyajikan informasi penting tentang kemajuan penerapan 5R dan temuan permasalahan yang ada seperti : jadwal audit 5R, hasil audit 5R, kemajuan yang telah dicapai dalam menjalankan 5R, laporan permasalahan yang terjadi, lokasi terjadinya permasalahan, siapa yang bertanggung jawab dalam melakukan penanggulanangan atas permasalahan yang ditemukan serta status penyelesaian perbaikan yang dilakukan apakah sudah terlaksana atau belum 


\section{PENUTUP}

\section{KESIMPULAN}

Terbentuknya budaya $5 \mathrm{R}$ yang baik sesuai yang diharapkan dapat menjadi mekanisme yang efektif dalam menemukan potensi perbaikan dari yang berskala kecil maupun besar karena aktifitas $5 \mathrm{R}$ yang konsisten dan efektif akan mampu menemukan aspek pemborosan yang ada disetiap dilingkungan kerja. Sehingga dengan demikian semakin terciptanya penerapana $5 \mathrm{R}$ yang berhasil dan tepat sasaran sesuai kebijakan manajemen dalam menjalankan $5 \mathrm{R}$ yang berhasil maka akan semakin memungkinkan tim kerja anda untuk melakaukan kaizen (continuous Improvement/perbaikan berkesinambungan yang berbasis $5 R$ dengan frekwensi yang lebih besar dengan hasil yang lebih besar. Kemajuan yang dicapai dengan selalu

\section{DAFTAR PUSTAKA}

Imai, Masaaki. 1999, Gemba Kaizen : Pendekatan Akal Sehat, Berbiaya Rendah Pada Manajemen, Penerbit PPM, Jakarta.

Kreitner dan Knick.2005. Perilaku Organisasi Edisi pertama.. Jakarta: SalembaEmpat.

Noe, Raymond A., et. al. 2010. Human Resource Management, Gaining Competitive Advantage 3rd Edition. McGraw-Hill.

Osada, Takashi.1995. "Sikap Kerja 5R". Jakarta : PT. Pustaka Binaman Pressindo. melakukan perbaikan yang berbasis $5 R$ akan melebihi kesempurnaan yang ada. Dalam filosofi kaizen tidak boleh merasa puas dari apa yang telah dicapai karena ketika dalam diri kita tertanam prinsip untuk selalu lebih baik dari waktu kewaktu. Mulailah hari ini... dengan selalu berprinsip tidak ada yang baik tapi selalu ada yang lebih baik

Proses kaizen 5R berkaitan erat dengan pembentukan budaya perusahaan. Kaizen $5 R$ dapat dilakukan seiring dengan peningkatan kedisiplinan lingkungan sekitar tempat pekerjaan. Dimulai dari menyederhanakan penyimpanan peralatan yang diperlukan di lingkungan kerja sehingga masuk ke tahap rapi, lalu kemudian menjadi resik kemudian dirawat dan dilakukan secara terus menerus akan menjadikan sebuah tempat kerja yang menyenangkan dengan pembentukan disiplin yang tidak memerlukan biaya besar.

Rivai, Veithzal. dan Mulyadi, Deddy. 2012. Kepemimpinan dan PerilakuOrganisasi. Edisi Ketiga. Jakarta: PT. Raja Grafindo Persada.

Robbins, Stephen P. 2008. Perilaku Organisasi Edisi 12 Buku 1 dan 2. Jakarta:Salemba Empat.

Simamora, Henry, 2004, Manajemen Sumber Daya Manusia, Edisi Ketiga, Cetakan Pertama, Bagian Penerbitan STIE YKPN, Yogyakarta.

Sinungan, Muchdarsyah. 2003. Produktivitas, Apa dan Bagaimana. Jakarta : BinaAksara. 
Supriyanto, Agus. 2014. Pengaruh Sikap Kerja 5 S (Seiri, Seiton, Seiso, Seiketsu,Shitsuke) terhadap Produktivitas.Riset Manajemen \& Akuntansi Volume 5Nomor 9.

Tika, H. Moh. Pabundu. 2010. Budaya Organisasi dan Peningkatan KinerjaPerusahaan. Jakarta : PT. Bumi Aksara.

Umar, H., 2010. Desain Penelitian MSDM dan Perilaku Karyawan. Paradigma

Wibowo. 2010. Budaya Organisasi. Jakarta: Rajawali Pers.
Osada, T. (2011). Sikap Kerja 5R. Jakarta: PPM

Jahja, Kristanto. (2009). Seri Budaya Unggulan 5R (Ringkas, Rapi, Resik, Rawat, Rajin), 3 ed. Jakarta: Productivity and Quality Management Consultans th

Wolio, Shopfloor Management \& Genba Kaizen Specialist. Evaluasi Penerapan Metode 5R Dalam Peningkatan Produktivitas; Strategi Menerapkan Metode 5R yang Effektif di Perusahaan. Jurnal Reka Integra. Teknik Industri No $04 \mathrm{Vol}$ 02. ITENAS. 2015. Bandun.g 